\title{
APPLICATION OF CUCKOO SEARCH METHOD IN 3D SLOPE STABILITY ANALYSIS FOR LIMESTONE QUARRY MINE
}

\author{
APLIKASI METODE CUCKOO SEARCH PADA ANALISIS \\ KESTABILAN LERENG 3D UNTUK TAMBANG KUARI BATU \\ GAMPING
}

\author{
MASAGUS A. AZIZI ${ }^{a}$, IRFAN MARWANZAa, NADYA A. HARTANTIª, MUHAMMAD K. \\ GHIFARI $^{a}$, AFIAT ANUGRAHADI ${ }^{b}$, and ZULFAHMIc \\ a Mining Engineering Department, Trisakti University \\ Jalan Kyai Tapa No.1, Grogol, Jakarta Barat 11440 \\ e-mail: masagus.azizi@trisakti.ac.id \\ ${ }^{b}$ Geology Engineering Department, Trisakti University, \\ Jalan Kyai Tapa No.1, Grogol, Jakarta Barat 11440 \\ ${ }^{c}$ R \& D Centre for Mineral and Coal Technology, Bandung, Indonesia \\ Jalan Jenderal Sudirman 6 Bandung 40211
}

\begin{abstract}
The Cuckoo Search (CS) is a very fast and efficient global optimization method to locating the slip surface which carried out by iteration. However, the Grid Search (conventional method) method in 3D slope stability analysis takes longer than this method on the computation process. Slope stability analysis was performed using the 3D limit equilibrium method "Bishop" with Cuckoo Search of slip surface by maximizing iteration of the simulation and columns in $\mathrm{X}$ or $\mathrm{Y}$. To ensure that the slip surface within the global minimum slip surface, the maximum iteration in CS was also specified from 40 to 1200 . Based on maximum columns in $\mathrm{X}$ or $\mathrm{Y}$, the safety factor value of the 3D CS results was then compared to the Grid Search results to determine the final 3D safety factor and the estimated volume of potential failure. The final 3D safety factor obtained from the average 3D safety factor (with maximum iteration 400, 800, 1000, and 1200) is about 2,01 with the average estimated volume of slope failure of $190.000 \mathrm{~m}^{3}$ that located at the north of the pit.
\end{abstract}

Keywords: open pit mine, limestone, slope stability analysis, 3D-limit equilibrium method, Cuckoo Search.

\begin{abstract}
ABSTRAK
Cuckoo Search (CS) adalah metode pengoptimalan global yang sangat cepat dan efisien dalam menemukan lokasi permukaan gelincir. Pencarian dilakukan dengan iterasi, sedangkan pada analisis kestabilan lereng 3D, metode Grid Search (metode konvensional) membutuhkan waktu yang lebih lama dibandingkan metode ini pada saat proses komputasi. Analisis stabilitas lereng dilakukan menggunakan metode kesetimbangan batas 3D "Bishop" dengan pencarian permukaan luncuran metode Cuckoo Search, dengan cara memaksimalkan iterasi variabel simulasi iterasi dan kolom $X$ atau $Y$. Untuk memastikan lokasi permukaan luncur pada saat seluruh permukaan tergelincir minimum, iterasi maksimum dalam CS juga ditentukan, mulai dari 40 hingga 1200. Berdasarkan kolom maksimum pada $X$ atau $Y$, nilai faktor keamanan hasil CS 3D kemudian dibandingkan dengan hasil Grid Search untuk menentukan faktor keamanan 3D akhir dan perkiraan volume potensi keruntuhan. Faktor keamanan 3D akhir yang diperoleh dari rata-rata (dengan iterasi maksimum 400, 800, 1000, dan 1200) sekitar 2,01 dengan perkiraan jumlah volume rata-rata keruntuhan lereng sebesar $190.000 \mathrm{~m}^{3}$ dan terletak di sebelah utara pit.
\end{abstract}

Kata kunci: tambang terbuka, batu gamping, kestabilan lereng, metode kesetimbangan batas 3D, Cuckoo Search. 


\section{INTRODUCTION}

Slope stability analysis in this research is performed using limit equilibrium method (LEM). Such the method requires slip surface assumption by calculating the safety factor (SF), namely circular or non-circular assumption. To obtain the surface with the lowest safety factor, the computation is performed in different potential slip surfaces (McCombie and Wilkinson, 2002). In 2D slope stability analysis, Grid Search is commonly used as a method to search slip surface because the principle is simple and easy-tounderstand. However, this method can only calculate the SF of circular slip surfaces, so it cannot represent the slope stability in real condition. The Cuckoo Search (CS) method with iteration process is useful to avoid manual determination and makes the calculation more representative. However, 3D-slope stability analysis with the grid search method takes longer than the CS on computation time.

Cuckoo Search (CS) is an algorithm used for solving the optimization problems. CS has been used in engineering field, such as welded beam and optimization in spring design but few used it for slope stability issue. Wu (2012) and Gandomi et al. (2013) used this method in 2D slope stability analysis. Wu (2012) did a performance comparison between simulated annealing (SA) and CS and concluded that the CS performance was better and more efficient than the SA. Gandomi et al. (2013) has implemented 3 latest swarm intelligence techniques in the model of 2D slope stability analysis which are adopted from few researches; considering that these 3 techniques have been carried out to solve the civil engineering problems. The 3 techniques involve firefly algorithm (FA), CS, and Levy Flight Krill Herd (LKH). The results of these applied techniques were compared to the traditional swarm intelligence technique, particle swarm optimization (PSO). The PSO results imply that CS and LKH were absolutely outperformed the traditional PSO, especially the LKH which demonstrates the best algorithm between those techniques in order to solve the complicated slope stability problems.

Nowadays, the necessity to analyze the slope stability in $3 \mathrm{D}$ approach is more essential. The reason is that slope stability problem should not be assumed in 2 dimensionally approach. It has been explained in Gens, Hutchinson and
Cavounidis (1988). The 2D analysis cannot be used as the main standard to assess the stability of open pit mine slope because it has not been considered as the spatial problem, thus a volume of potential failure of slope could not estimate in this approach (Azizi, Marwanza and Hartanti, 2018). The importance of estimation in a volume of slope failure is for risk calculation of slope failure. The risk is defined as a probability of slope failure multiply by consequences of slope failure (RodriguezLopez, Jimenez-Rodriguez and Hruskovic, 2006). The volume of slope failure is counted as one of the consequences. It can be obtained by analyzing the slope stability in the 3D approach. Furthermore, there is a relationship between the failure probability and the volume of failure (Azizi et al., 2014). Another issue is that when 3D analysis is performed using a Grid Search, the use of 3D slope stability analysis on a vast area can be complicated (Azizi et al., 2018). This supports the statement of Hu et al. (2015) that more advanced optimization methods are required in real cases. Therefore, through this research, the authors tried to apply the CS in order to determine the slip surface with minimum SF in 3D analysis. Thus, the research suggest the CS as an alternative or other better option in 3D analysis. However, there is a weakness in this method. The geometric object is required to be in a good condition. When the object is damaged, it is necessary to cut the 3D pit model and manually determine the slip surface.

\section{METHODS}

Material in this location consists of 2 types of rocks, namely high-grade limestone and lowgrade limestone. The material properties for the high-grade limestone are unit weight 20.6 $\mathrm{kN} / \mathrm{m}^{3}$, cohesion $170 \mathrm{kPa}$, internal friction angle 53.0 degrees and tensile strength 2500 $\mathrm{kPa}$, whereas the low-grade limestone properties are unit weight $20.5 \mathrm{kN} / \mathrm{m}^{3}$, cohesion $120 \mathrm{kPa}$, internal friction angle 46.9 degrees and tensile strength $2250 \mathrm{kPa}$ (included geotechnical model adopted from Azizi et al. (2018). Slope stability analysis was performed in LEM 3D "Bishop" (Cheng and Yip, 2007) with Cuckoo Search (CS) of slip surface using simulation variable of max iteration and max columns in $\mathrm{X}$ or $\mathrm{Y}$. To ensure the slip surface was the global minimum slip surface, the maximum iteration in CS was also specified from 40 to 1200. 
Based on max columns in $\mathrm{X}$ or $\mathrm{Y}, \mathrm{SF}$ value of the 3D CS results were then compared to the Grid Search results as carried out by Azizi et al. (2018) to determine the final 3D SF, and the estimated volume of potential failure. Finally, it would be clear if the CS could be used in analyzing slope stability or not. In this research, the authors using Slide3 of Rocscience software that has a basic concept of slip surface search methods.

\section{CUCKOO SEARCH (CS)}

CS is a metaheuristic optimization method (Yang, 2014) that was developed by Yang and Deb (2010). The method was inspired from cuckoo's breeding behavior. In this research, the CS is used as a slip surface search tool that has the lowest SF. CS is coupled with Lévy Flights random walk. There are few rules to use this algorithm as stated in Yang and Deb (2009):

- Each cuckoo lay one egg at a time, and dumps it in a randomly chosen nest;

- The best nests with high quality of eggs (solutions) will carry over to the next generations;

- The number of available host nests is fixed, and a host can discover an alien egg with a probability $p a \in[0,1]$. In this case, the host bird can either throw the egg away or abandon the nest so as to build a completely new nest in a new location.

The last rule can be approached using a fraction $p_{a}$ to determine the worst solutions of $\mathrm{n}$ nests that will be replaced with a new nest randomly. In order to solve the problem, it can be simply illustrated that every egg in a nest represents one new solution. The purpose is to use the new and potentially better solution to replace the current solution in the nest. In a certain condition, the nest may have 2 eggs ( 2 solutions) but this problem is simplified so one nest has only 1 solution (Yang and Deb, 2010; Mohammed and Duaimi, 2018).

The random walk as determined by Lévy Flights can be described in the following formula: $\mathrm{x}_{\mathrm{i}}^{(\mathrm{t}+1)}=\mathrm{x}_{\mathrm{i}}^{(\mathrm{t})}+\alpha \oplus \operatorname{Lévy}(\lambda)$

where $\alpha>0$ is the step size and Lévy $(\lambda)$

is the position function from Lévy

Flights.

Lévy $\sim \mathrm{u}=\mathrm{t}^{-\lambda},(1<\lambda \leq 3)$

CS has been applied in many optimizations and computer intelligence with promising efficiency. As stated in Yang and Deb (2014) this has been proved from design application in engineering field, scheduling problems, thermodynamic calculations, etc. Few examples of CS application in engineering field are designing spring, welded beam, and steel frame. The CS's performance has also been compared with some metaheuristic algorithms such as PSO and Genetic Algorithm (GA), and the result shows that the CS has a higher success rate than the two others (Yang and Deb, 2009).

One of case studies using the CS approach in slope stability analysis is an open cut coal mine in Queensland, Australia.

LEM 3D "Janbu" was used to determine the likely behavior of an open cut coal mine excavated slope. As the slope's actual performance was known, this was an ideal case study to test the reliability of the slope stability analysis methodology in Slide3 (McQuillan et al., 2018).

\section{RESULT AND DISCUSSION}

The topographic map, pit design and drill point data are overlaid to produce a geotechnical model (Figure 1). The model is used for a 3D pit modeling by importing it into the Slide3 software to produce a 3D pit model that is ready for slope stability analysis (Figure 2). After the stability of the slopes is analyzed using the LEM 3D "Bishop" method, the results are presented in Tables 1 and 2.

An example of the results of the analysis using the max iteration and max column variables in the $x$ and $y$ directions in the search for the slip surface using the CS method can be seen in the Figure 3, 4 and 5. 
INDONESIAN MINING JOURNAL Vol. 23, No. 2, October $2020: 57$ - 65

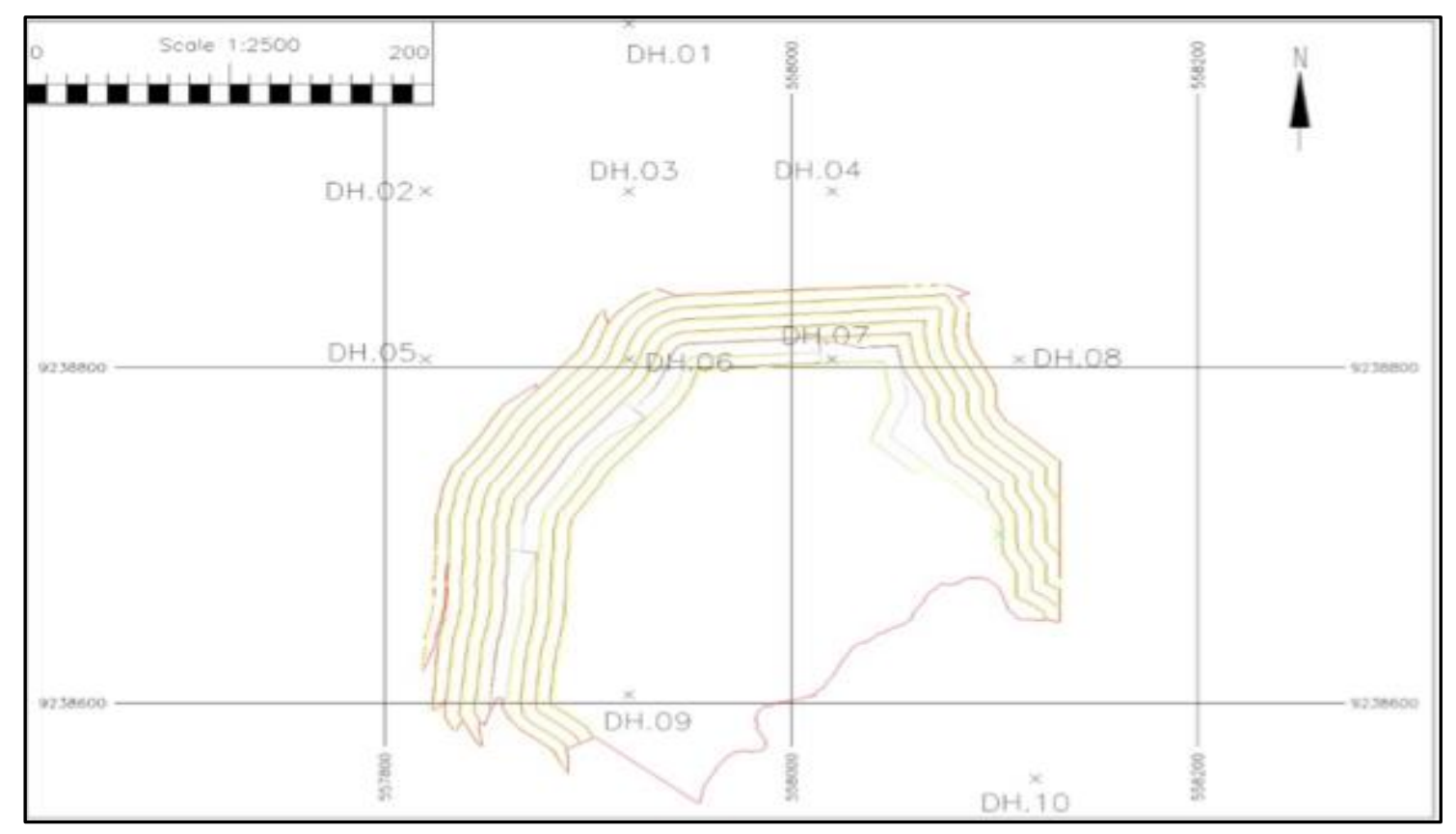

Figure 1. Geotechnical for slope stability analysis model

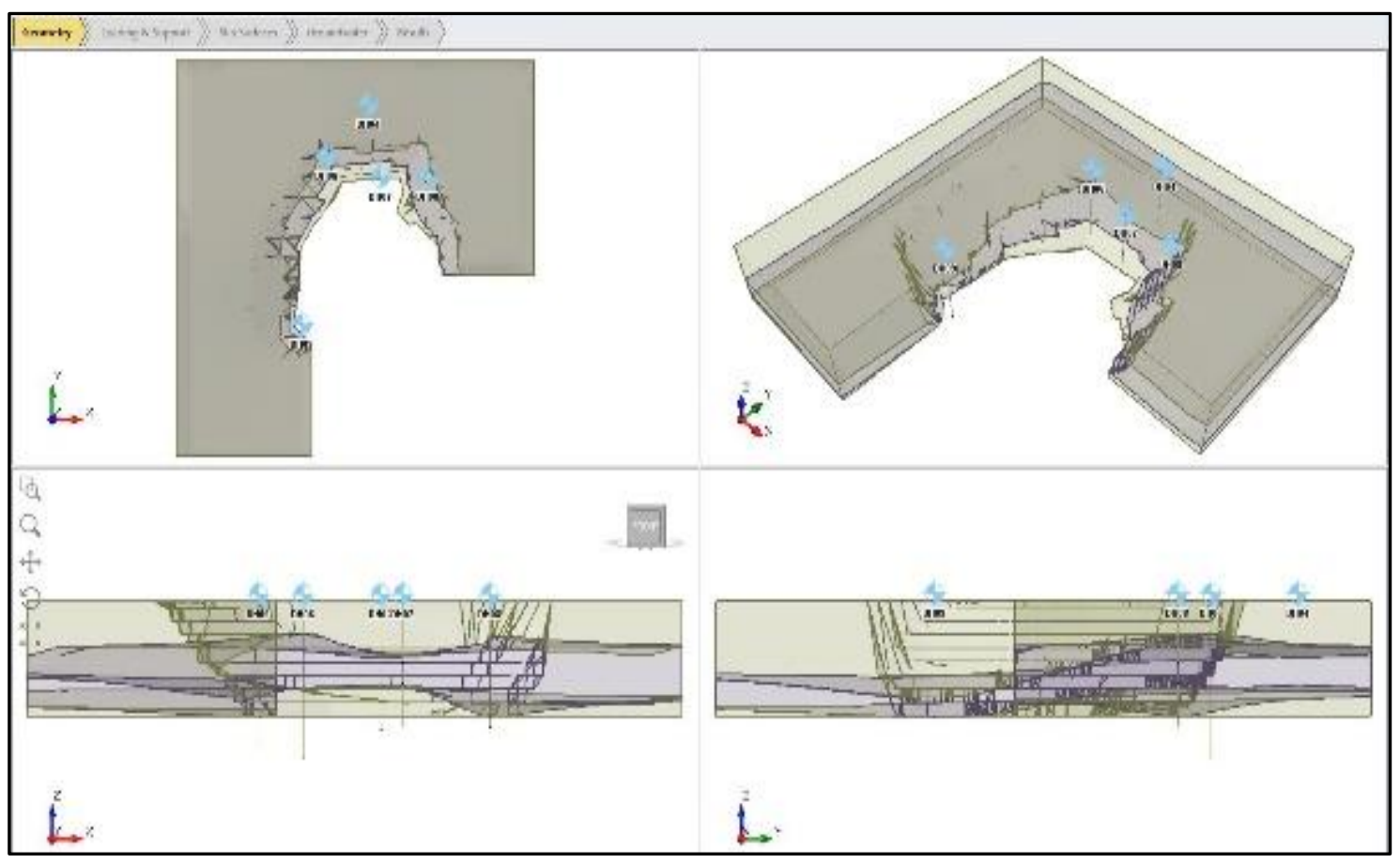

Figure 2. 3D pit model in Slide3 
Application of Cuckoo Search Method in 3D Slope Stability Analysis ... Masagus A. Azizi et al.

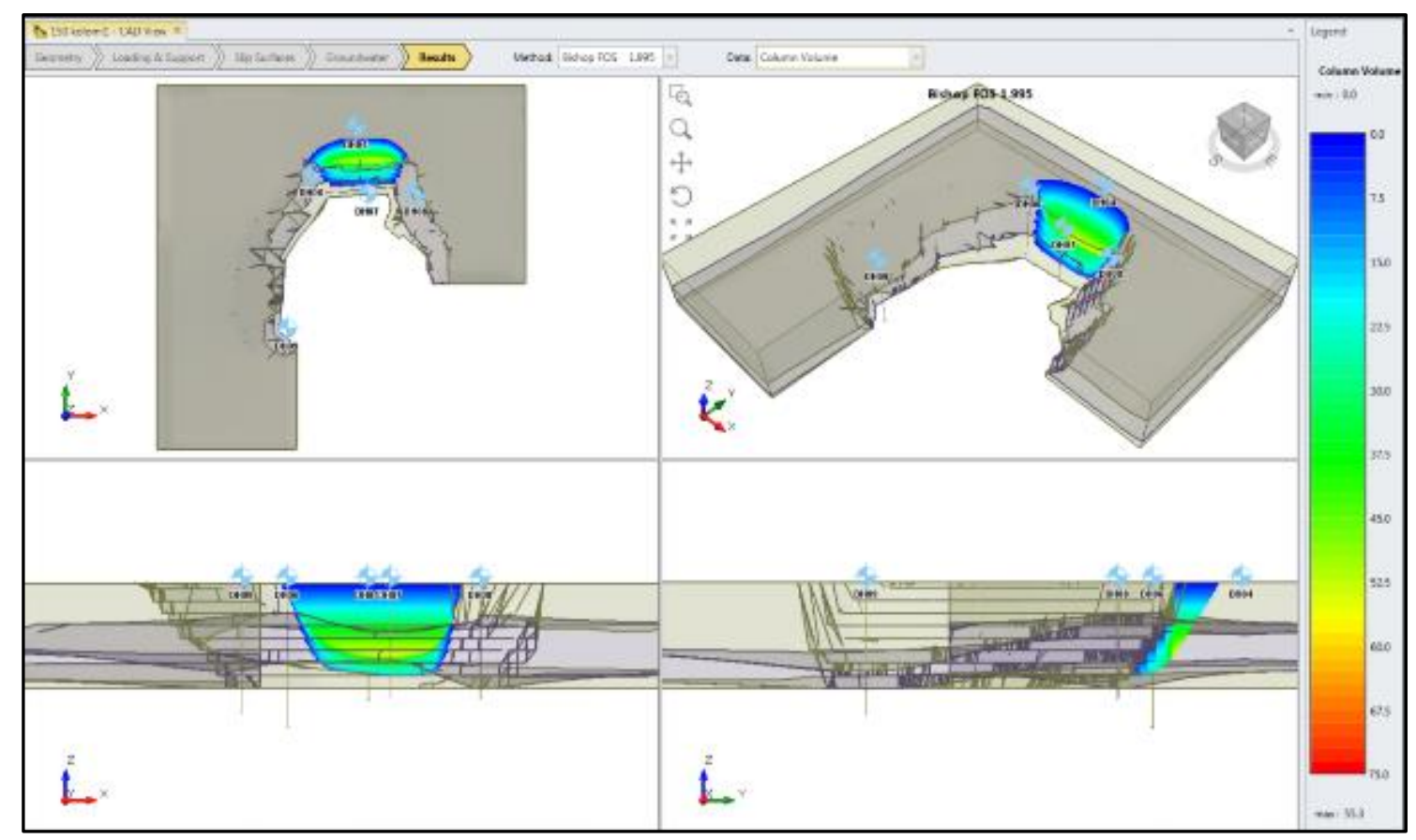

Figure 3. The display of 3D analysis result using Max Columns in $X$ or $Y 150$ and maximum CS iteration 1000

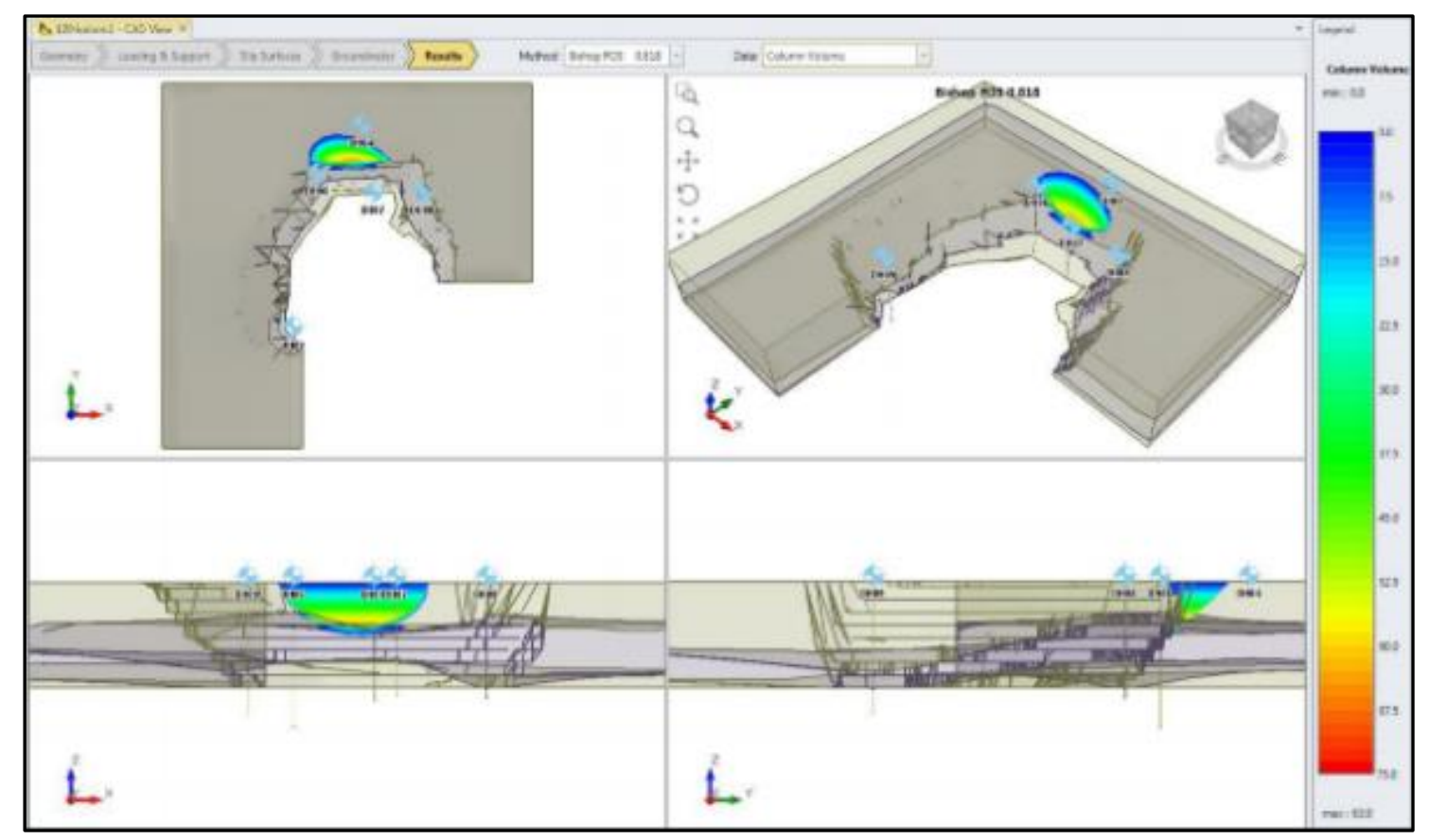

Figure 4. The display of 3D analysis result using Max Columns in $X$ or $Y 120$ and maximum CS iteration 1200 


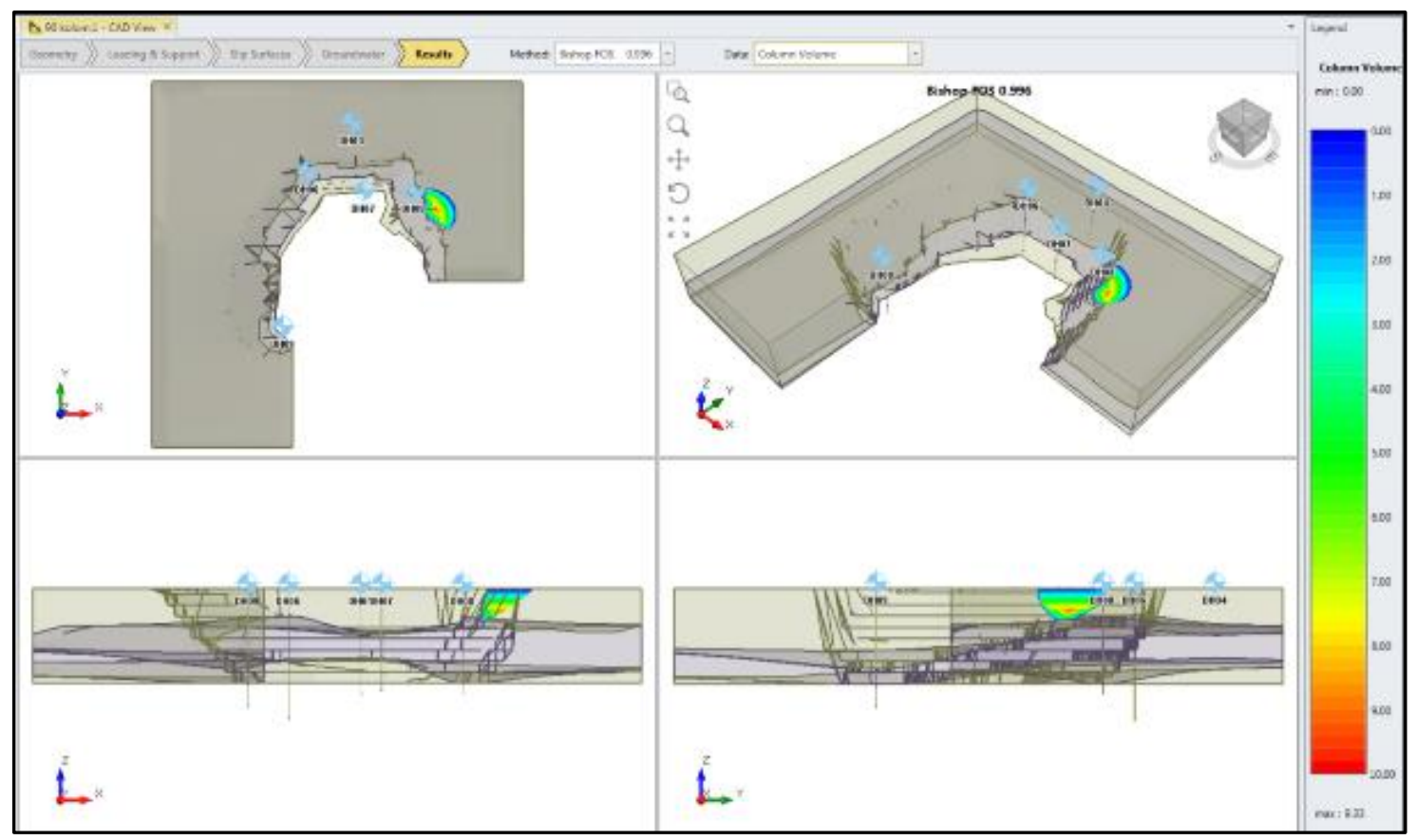

Figure 5. The display of 3D analysis result using Max Columns in X or $Y 90$ and maximum CS iteration 160

From 3D CS results (Table 1), the critical position of the slip surface is in the northern pit. It shows that there are few outliers, which happened because of the CS performance itself. Yang and Deb (2010) and Yang (2014) in Gandomi et al. (2013) stated that there is no guarantee in discovering the best solution, or when an algorithm will work and why it can work.

Based on the 3D Grid Search result in Azizi et al. (2018), the final global minimum location was directed at the north of the pit. The same result is obtained from $3 \mathrm{D}$ CS result. The comparison between the average 3D SF using CS and Grid Search (Table 2) enumerates that the difference is only 0,01 (the averaged 3D CS SF and 3D Grid Search SF values are almost the same). Therefore, the research concludes that the CS and Grid Search can be reliable in seeking the global minimum slip surface. However, judging from the efficiency of both methods, the CS is more efficient than the Grid Search. The computation time to get the SF in Grid Search was longer than that of the CS computation time. This is because Grid Search depends on the number of points assigned. The more points are assigned, the longer computational time will be. The incoming problem will occur if 3D analysis using Grid Search performed on a vast area. Indeed, the larger the area, the larger grid box should be made, and if it needs accuracy, the number of points should be made tightly. Albataineh (2006) has stated that automating the search techniques can be a cumbersome task if using classic search techniques. Advanced optimization techniques showed promising potential for further developments and future applications in slope stability and in geotechnical engineering (Albataineh, 2006).

Based on the results of 3D CS analysis, it shows that most of the locations with the lowest SF are located in the north and northeast of the pit. The difference in the global minimum location is caused unmet requirement of global minimum in the quest, and only after the increase in iteration that the potential of failure at north of the pit could be located entirely, as indicated by the results with maximum iteration of $400,800,1000$, and 1200. Subsequently, the final 3D SF obtained from the average 3D SF (with maximum iteration $400,800,1000$, and 1200) is about 2,01 with the average estimated volume of potential failure of $190.000 \mathrm{~m}^{3}$ and located at the north of the pit. 
Application of Cuckoo Search Method in 3D Slope Stability Analysis ... Masagus A. Azizi et al.

Table 1. Recapitulation of 3D CS analysis results

\begin{tabular}{|c|c|c|c|c|c|}
\hline $\begin{array}{c}\text { Max } \\
\text { Iteration }\end{array}$ & $\begin{array}{c}\text { Max } \\
\text { Columns } \\
\text { in } \mathrm{X} \text { or } \mathrm{Y}\end{array}$ & Fos & $\begin{array}{l}\text { Volume } \\
\qquad\left(\mathrm{m}^{3}\right)\end{array}$ & Location & $\begin{array}{c}\text { Slip } \\
\text { Surface } \\
\text { Position }\end{array}$ \\
\hline \multirow{11}{*}{40} & 50 & 2.06 & 159816 & north & $\mathrm{a}$ \\
\hline & 60 & 2.02 & 179523 & north & a \\
\hline & 70 & 2.10 & 229704 & northeast & - \\
\hline & 80 & 2.10 & 303186 & northeast & - \\
\hline & 90 & 2.01 & 183631 & north & a \\
\hline & 100 & 2.01 & 187898 & north & a \\
\hline & 110 & 2.00 & 185461 & north & a \\
\hline & 120 & 2.14 & 178230 & northeast & - \\
\hline & 130 & 2.10 & 255444 & northeast & - \\
\hline & 140 & 2.09 & 297896 & northeast & - \\
\hline & 150 & 2.11 & 297771 & northeast & - \\
\hline \multirow{11}{*}{80} & 50 & 2.03 & 179192 & north & $a$ \\
\hline & 60 & 2.02 & 192951 & north & a \\
\hline & 70 & 2.03 & 167961 & north & a \\
\hline & 80 & 2.02 & 178858 & north & a \\
\hline & 90 & 2.02 & 171821 & north & a \\
\hline & 100 & 2.01 & 183469 & north & a \\
\hline & 110 & 2.11 & 298457 & northeast & - \\
\hline & 120 & 2.17 & 170457 & northeast & - \\
\hline & 130 & 2.00 & 183204 & north & a \\
\hline & 140 & 2.01 & 191916 & north & a \\
\hline & 150 & 2.10 & 265182 & northeast & - \\
\hline \multirow{11}{*}{120} & 50 & 2.02 & 175113 & north & $a$ \\
\hline & 60 & 2.02 & 180573 & north & a \\
\hline & 70 & 2.01 & 178671 & north & a \\
\hline & 80 & 2.01 & 193606 & north & a \\
\hline & 90 & 2.01 & 180490 & north & a \\
\hline & 100 & 2.02 & 190336 & north & a \\
\hline & 110 & 2.11 & 272365 & northeast & - \\
\hline & 120 & 2.04 & 180305 & north & a \\
\hline & 130 & 2.08 & 167245 & north & a \\
\hline & 140 & 2.00 & 199989 & north & a \\
\hline & 150 & 2.00 & 195607 & north & $\mathrm{a}$ \\
\hline \multirow{11}{*}{160} & 50 & 2.00 & 194125 & north & $a$ \\
\hline & 60 & 2.01 & 174180 & north & a \\
\hline & 70 & 2.03 & 170430 & north & a \\
\hline & 80 & 2.01 & 179233 & north & a \\
\hline & 90 & 1.00 & 19008 & northeast & $b$ \\
\hline & 100 & 1.99 & 199321 & north & a \\
\hline & 110 & 2.04 & 174759 & north & a \\
\hline & 120 & 2.00 & 194403 & north & a \\
\hline & 130 & 2.00 & 194988 & north & a \\
\hline & 140 & 2.00 & 191965 & north & a \\
\hline & 150 & 2.00 & 191338 & north & a \\
\hline \multirow{11}{*}{200} & 50 & 2.01 & 180821 & north & $a$ \\
\hline & 60 & 2.01 & 179535 & north & a \\
\hline & 70 & 2.10 & 258302 & northeast & - \\
\hline & 80 & 2.19 & 270897 & northeast & - \\
\hline & 90 & 2.04 & 172299 & north & a \\
\hline & 100 & 1.99 & 192171 & north & a \\
\hline & 110 & 2.10 & 315329 & northeast & - \\
\hline & 120 & 2.02 & 186531 & north & a \\
\hline & 130 & 2.09 & 303241 & northeast & - \\
\hline & 140 & 2.01 & 183645 & north & a \\
\hline & 150 & 1.99 & 197361 & north & a \\
\hline 400 & 50 & 2.00 & 195539 & north & $a$ \\
\hline
\end{tabular}

\begin{tabular}{|c|c|c|c|c|c|}
\hline $\begin{array}{c}\text { Max } \\
\text { Iteration }\end{array}$ & $\begin{array}{c}\text { Max } \\
\text { Columns } \\
\text { in } X \text { or } Y\end{array}$ & FoS & $\begin{array}{l}\text { Volume } \\
\qquad\left(\mathrm{m}^{3}\right)\end{array}$ & Location & $\begin{array}{c}\text { Slip } \\
\text { Surface } \\
\text { Position }\end{array}$ \\
\hline & 60 & 2.05 & 174848 & north & $a$ \\
\hline & 70 & 2.02 & 199719 & north & a \\
\hline & 80 & 2.00 & 195231 & north & a \\
\hline & 90 & 2.00 & 194572 & north & a \\
\hline & 100 & 2.00 & 186047 & north & a \\
\hline & 110 & 2.00 & 187918 & north & a \\
\hline & 120 & 2.01 & 190101 & north & a \\
\hline & 130 & 2.00 & 197552 & north & a \\
\hline & 140 & 2.00 & 197629 & north & a \\
\hline & 150 & 1.99 & 193761 & north & $\mathrm{a}$ \\
\hline \multirow{11}{*}{600} & 50 & 2.05 & 157244 & north & $a$ \\
\hline & 60 & 2.04 & 171805 & north & a \\
\hline & 70 & 2.02 & 178812 & north & a \\
\hline & 80 & 2.01 & 184185 & north & a \\
\hline & 90 & 2.00 & 200779 & north & a \\
\hline & 100 & 2.00 & 195602 & north & a \\
\hline & 110 & 2.00 & 191515 & north & a \\
\hline & 120 & 2.04 & 186207 & north & a \\
\hline & 130 & 1.02 & 21725 & $\begin{array}{c}\text { southwest- } \\
\text { west }\end{array}$ & $b$ \\
\hline & 140 & 2.03 & 185630 & north & a \\
\hline & 150 & 2.00 & 197891 & north & a \\
\hline \multirow{11}{*}{800} & 50 & 0.82 & 38239 & north & $b$ \\
\hline & 60 & 2.01 & 192786 & north & a \\
\hline & 70 & 2.01 & 204299 & north & a \\
\hline & 80 & 2.01 & 196060 & north & a \\
\hline & 90 & 2.01 & 187613 & north & a \\
\hline & 100 & 2.01 & 187709 & north & a \\
\hline & 110 & 1.99 & 197197 & north & a \\
\hline & 120 & 2.05 & 171951 & north & a \\
\hline & 130 & 2.00 & 195292 & north & a \\
\hline & 140 & 1.99 & 188645 & north & a \\
\hline & 150 & 2.00 & 203026 & north & a \\
\hline \multirow{11}{*}{1000} & 50 & 2.02 & 185006 & north & $a$ \\
\hline & 60 & 2.04 & 173577 & north & a \\
\hline & 70 & 2.03 & 175154 & north & a \\
\hline & 80 & 2.01 & 187845 & north & a \\
\hline & 90 & 2.01 & 189787 & north & a \\
\hline & 100 & 2.01 & 177988 & north & a \\
\hline & 110 & 2.01 & 187164 & north & a \\
\hline & 120 & 1.99 & 196072 & north & a \\
\hline & 130 & 2.00 & 195552 & north & a \\
\hline & 140 & 2.01 & 192773 & north & a \\
\hline & 150 & 2.00 & 182345 & north & $\mathrm{a}$ \\
\hline \multirow{11}{*}{1200} & 50 & 2.02 & 174381 & north & $a$ \\
\hline & 60 & 2.01 & 192164 & north & a \\
\hline & 70 & 2.02 & 196821 & north & a \\
\hline & 80 & 2.01 & 194283 & north & a \\
\hline & 90 & 2.00 & 195594 & north & a \\
\hline & 100 & 2.01 & 198190 & north & a \\
\hline & 110 & 2.00 & 191729 & north & a \\
\hline & 120 & 0.82 & 64369 & north & $b$ \\
\hline & 130 & 2.01 & 189788 & north & a \\
\hline & 140 & 2.00 & 184077 & north & a \\
\hline & 150 & 2.00 & 188461 & north & a \\
\hline
\end{tabular}


Table 2. The difference between 3D SF using CS and Grid Search

\begin{tabular}{|c|c|c|c|c|}
\hline \multirow{2}{*}{$\begin{array}{c}\text { Max } \\
\text { Columns in } \\
X \text { or } Y\end{array}$} & \multicolumn{2}{|c|}{ Grid Search } & \multicolumn{2}{|c|}{ Cuckoo Search } \\
\hline & $\begin{array}{c}\text { Number of } \\
\text { Radii per Point }\end{array}$ & SF & $\begin{array}{c}\text { Max } \\
\text { Iteration }\end{array}$ & SF \\
\hline \multirow{5}{*}{50} & 10 & 2.11 & 400 & 2.00 \\
\hline & 20 & 2.04 & 800 & $x$ \\
\hline & 30 & 2.04 & 1000 & 2.02 \\
\hline & 40 & 2.04 & 1200 & 2.02 \\
\hline & 50 & 2.01 & & \\
\hline \multirow{5}{*}{60} & 10 & 2.09 & 400 & 2.05 \\
\hline & 20 & 2.00 & 800 & 2.01 \\
\hline & 30 & 2.01 & 1000 & 2.04 \\
\hline & 40 & 2.00 & 1200 & 2.01 \\
\hline & 50 & 2.03 & & \\
\hline \multirow{5}{*}{70} & 10 & 2.01 & 400 & 2.02 \\
\hline & 20 & 2.00 & 800 & 2.01 \\
\hline & 30 & 2.00 & 1000 & 2.03 \\
\hline & 40 & 2.00 & 1200 & 2.02 \\
\hline & 50 & 2.02 & & \\
\hline \multirow{5}{*}{80} & 10 & 2.02 & 400 & 2.00 \\
\hline & 20 & 2.01 & 800 & 2.01 \\
\hline & 30 & 2.00 & 1000 & 2.01 \\
\hline & 40 & 2.01 & 1200 & 2.01 \\
\hline & 50 & 2.02 & & \\
\hline \multirow{5}{*}{90} & 10 & 1.99 & 400 & 2.00 \\
\hline & 20 & 2.01 & 800 & 2.01 \\
\hline & 30 & 2.01 & 1000 & 2.01 \\
\hline & 40 & 2.01 & 1200 & 2.00 \\
\hline & 50 & 2.00 & & \\
\hline \multirow{4}{*}{100} & 10 & 2.03 & 400 & 2.00 \\
\hline & 20 & 2.00 & 800 & 2.01 \\
\hline & 30 & 2.06 & 1000 & 2.01 \\
\hline & 40 & 2.00 & 1200 & 2.01 \\
\hline
\end{tabular}

\section{CONCLUSION}

Based on the discussion, CS can be used as the best alternative option to determine SF using LEM 3D "Bishop" without making an assumption of slip surface. Based on the max iteration values in $X$ or $Y$, the difference in the safety factor between the grid search method and CS is relatively small. Moreover, the research find that it is more efficient to use the CS than the Grid Search on computation time. Using LEM 3D "Bishop" with CS approach, the SF is obtained 2.00 with estimated volume of slope failure in 190,000 $\mathrm{m}^{3}$, and the location of the lowest SF is the north of the pit.

\section{ACKNOWLEDGEMENT}

The authors would like to thank the Mining Engineering Department, Faculty of Earth Technology and Energy, Trisakti University for facilitating the software and Rocscience, Inc. as the provider of the software in supporting this research.

\begin{tabular}{|c|c|c|c|c|}
\hline \multirow{2}{*}{$\begin{array}{c}\text { Max } \\
\text { Columns in } \\
X \text { or } Y\end{array}$} & \multicolumn{2}{|c|}{ Grid Search } & \multicolumn{2}{|c|}{ Cuckoo Search } \\
\hline & $\begin{array}{c}\text { Number of } \\
\text { Radii per Point }\end{array}$ & SF & $\begin{array}{c}\text { Max } \\
\text { Iteration }\end{array}$ & SF \\
\hline & 50 & 1.99 & & \\
\hline \multirow{5}{*}{110} & 10 & 2.00 & 400 & 2.00 \\
\hline & 20 & 2.01 & 800 & 1.99 \\
\hline & 30 & 2.02 & 1000 & 2.01 \\
\hline & 40 & 2.01 & 1200 & 2.00 \\
\hline & 50 & 1.92 & & \\
\hline \multirow{5}{*}{120} & 10 & 2.00 & 400 & 2.01 \\
\hline & 20 & 2.00 & 800 & 2.05 \\
\hline & 30 & 2.08 & 1000 & 1.99 \\
\hline & 40 & 2.00 & 1200 & $x$ \\
\hline & 50 & 2.00 & & \\
\hline \multirow{5}{*}{130} & 10 & 2.00 & 400 & 2.00 \\
\hline & 20 & 2.00 & 800 & 2.00 \\
\hline & 30 & 2.07 & 1000 & 2.00 \\
\hline & 40 & 2.00 & 1200 & 2.01 \\
\hline & 50 & 1.99 & & \\
\hline \multirow{5}{*}{140} & 10 & 2.01 & 400 & 2.00 \\
\hline & 20 & 2.00 & 800 & 1.99 \\
\hline & 30 & 2.00 & 1000 & 2.01 \\
\hline & 40 & 2.00 & 1200 & 2.00 \\
\hline & 50 & 2.02 & & \\
\hline \multirow{5}{*}{150} & 10 & 2.01 & 400 & 1.99 \\
\hline & 20 & 2.00 & 800 & 2.00 \\
\hline & 30 & 2.06 & 1000 & 2.00 \\
\hline & 40 & 2.00 & 1200 & 2.00 \\
\hline & 50 & 2.01 & & \\
\hline \multicolumn{2}{|c|}{ Average } & 2.01 & & 2.00 \\
\hline \multicolumn{2}{|c|}{ Delta } & & 0.01 & \\
\hline
\end{tabular}

\section{REFERENCES}

Albataineh, N. (2006) Slope stability analysis using 2D and 3D methods. University of Akron.

Azizi, M. A. et al. (2014) "Risk assessment of open pit slope design at PT Adaro Indonesia," Indonesian Mining Journal, 17(3), pp. 113-121.

Azizi, M. A. et al. (2018) "Three dimensional slope stability analysis of open pit limestone mine in Rembang District, Central Java," IOP Conference Series: Earth and Environmental Science, 212, p. 012035. doi: 10.1088/1755-1315/212/1/012035.

Azizi, M. A., Marwanza, I. and Hartanti, N. A. (2018) "Penentuan volume potensi longsoran lereng tambang terbuka menggunakan metode kesetimbangan batas 3 dimensi," in Prosiding XXVII dan Kongres X PERHAPI 2018. Jakarta: PERHAPI, pp. 173-183.

Cheng, Y. M. and Yip, C. J. (2007) "Threedimensional asymmetrical slope stability analysis extension of Bishop's, Janbu's, and Morgenstern-Price's techniques," Journal of Geotechnical and 
Geoenvironmental Engineering, 133(12), pp. 1544-1555.

doi: 10.1061/(ASCE)1090-0241(2007)

133:12(1544).

Gandomi, A. H. et al. (2013) "Metaheuristic algorithms in modeling and optimization," in Metaheuristic Applications in Structures and Infrastructures. Elsevier, pp. 1-24. doi: 10.1016/B978-0-12-398364-0.000012.

Gens, A., Hutchinson, J. N. and Cavounidis, S. (1988) "Three-dimensional analysis of slides in cohesive soils," Géotechnique, 38(1), pp. 1-23.

doi: 10.1680/geot.1988.38.1.1.

$\mathrm{Hu}, \mathrm{C}$. et al. (2015) "Determination of critical slip surfaces using mutative scale chaos optimization," Journal of Computing in Civil Engineering, 29(5), p. 04014067. doi: 10.1061/(ASCE)CP.1943-5487.0000373.

McCombie, P. and Wilkinson, P. (2002) "The use of the simple genetic algorithm in finding the critical factor of safety in slope stability analysis," Computers and Geotechnics, 29(8), pp. 699-714. doi: 10.1016/S0266-352X(02)00027-7.

McQuillan, A. et al. (2018) Case study: Comparing slide3 models to actual slope failure in an open cut coal mine, www.rocscience.com. Available at:

https://www.rocscience.com/documents/p $\mathrm{dfs} /$ rocnews/2018spring/Slide3 Case Study.pdf (Accessed: June 22, 2020).

Mohammed, R. A. and Duaimi, M. G. (2018) "Association rules mining using cuckoo search algorithm," International Journal of Data Mining, Modelling and Management, 10(1), p. 73.

doi: 10.1504/IJDMMM.2018.089630.
Rodriguez-Lopez, F., Jimenez-Rodriguez, R. and Hruskovic, P. (2006) "Geotechnical risk management as a basis for quality assurance," in Risk Analysis V: Simulation and Hazard Mitigation. Southampton, UK: WIT Press (WIT Transactions on Ecology and the Environment, Vol 91), pp. 79-86. doi: 10.2495/RISK060081.

Wu, A. (2012) Locating general failure surfaces in slope analysis via Cuckoo search, www.rocscience.com. Available at: https://www.rocscience.com/help/slide2/ pdf_files/theory/Cuckoo_Search.pdf (Accessed: May 9, 2018).

Yang, X.-S. (2014) "Genetic algorithms," in Nature-Inspired Optimization Algorithms. Elsevier, pp. 77-87. doi: 10.1016/B9780-12-416743-8.00005-1.

Yang, X.-S. and Deb, S. (2009) "Cuckoo search via Lévy flights," in 2009 World Congress on Nature \& Biologically Inspired Computing (NaBIC). IEEE, pp. 210-214. doi: 10.1109/NABIC.2009.5393690.

Yang, X.-S. and Deb, S. (2014) "Cuckoo search: Recent advances and applications," Neural Computing and Applications, 24(1), pp. 169-174. doi: $10.1007 / s 00521-013-1367-1$.

Yang, X. S. and Deb, S. (2010) "Engineering optimisation by cuckoo search," International Journal of Mathematical Modelling and Numerical Optimisation, 1(4), p. 330. doi: 10.1504/IJMMNO.2010.035430. 
